\title{
REFUGEES
}

AND THE VIOLENCE OF

WELFARE BUREAUCRACIES

IN NORTHERN EUROPE
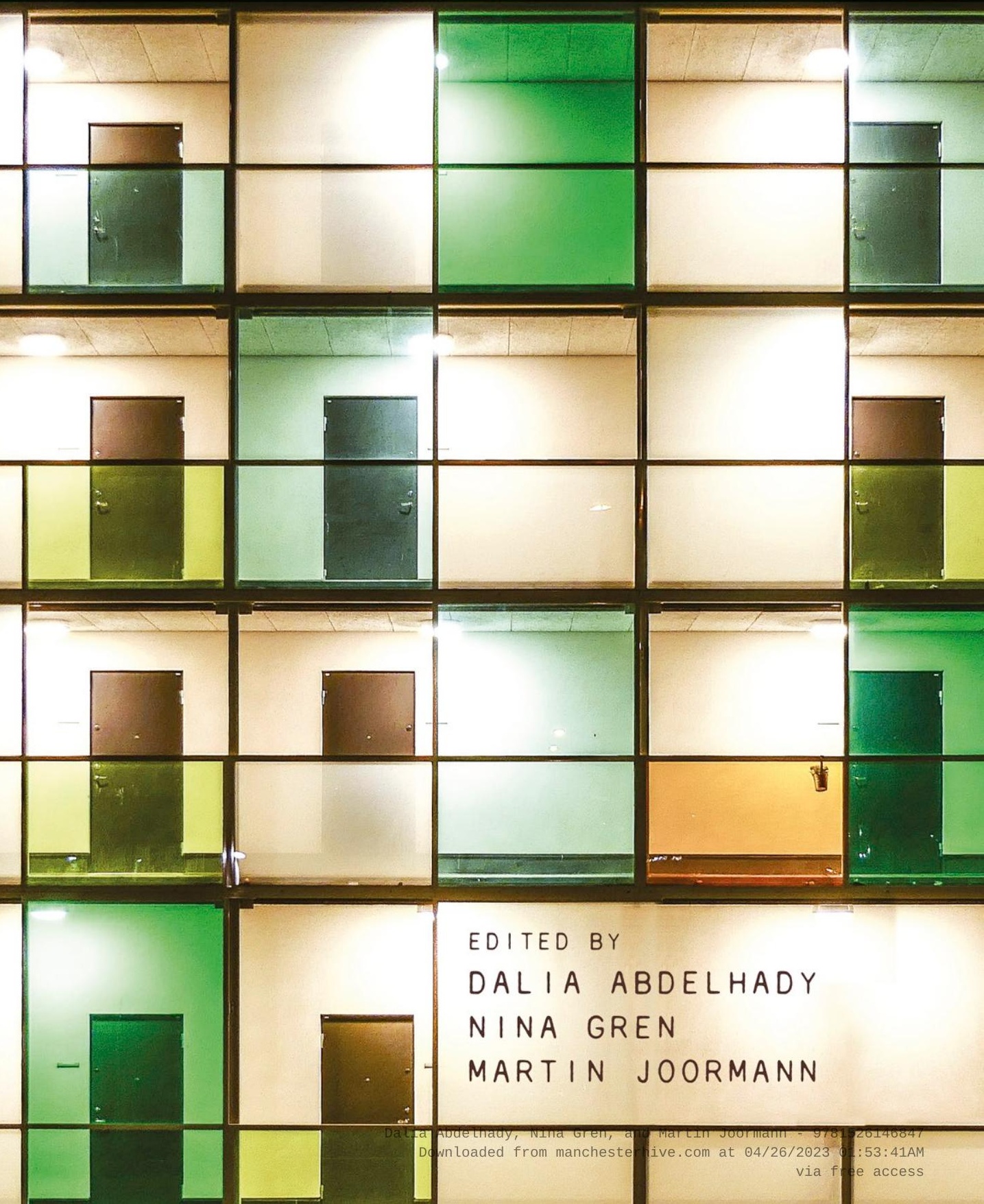


\section{Refugees and the violence of welfare bureaucracies in Northern Europe}

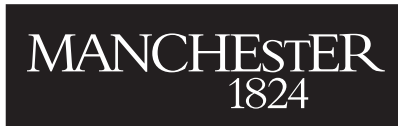

Manchester University Press 
Dalia Abdelhady, Nina Gren, and Martin Joormann - 9781526146847 Downloaded from manchesterhive.com at 04/26/2023 01:53:41AM 


\section{Refugees and the violence of welfare bureaucracies in Northern Europe}

Edited by

Dalia Abdelhady, Nina Gren and Martin Joormann

Manchester University Press 
Copyright (C) Manchester University Press 2020

While copyright in the volume as a whole is vested in Manchester University Press, copyright in individual chapters belongs to their respective authors.

This electronic version has been made freely available under a Creative Commons (CC-BY-NC-ND) licence, thanks to the support of Lund University Library, which permits non-commercial use, distribution and reproduction provided the author(s) and Manchester University Press are fully cited and no modifications or adaptations are made. Details of the licence can be viewed at https:// creativecommons.org/licenses/by-nc-nd/4.0/.

Published by Manchester University Press

Altrincham Street, Manchester M1 7JA

www.manchesteruniversitypress.co.uk

British Library Cataloguing-in-Publication Data

A catalogue record for this book is available from the British Library

ISBN 9781526146830 hardback

ISBN 9781526146847 open access

First published 2020

The publisher has no responsibility for the persistence or accuracy of URLs for any external or third-party internet websites referred to in this book, and does not guarantee that any content on such websites is, or will remain, accurate or appropriate.

Typeset

by New Best-set Typesetters Ltd 